\title{
Effect of Hydrothermal Activity on Organic Matter Enrichment of Shale: A Case Study of the Upper Ordovician and the Lower Silurian in the Lower Yangtze, South China
}

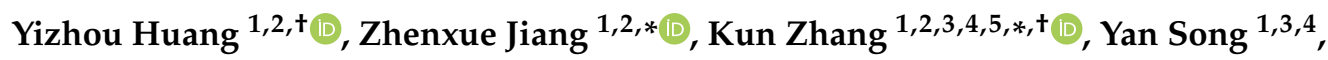 \\ Shu Jiang $5,6,7 \oplus$, Weiwei Liu ${ }^{8}$, Ming Wen ${ }^{1,2}, \mathrm{Xin} \mathrm{Li}^{1,2}{ }^{1}$, Xuelian Xie ${ }^{9}$, Tianlin Liu ${ }^{1,2}$, \\ Xiangni Cao ${ }^{1,2}$, Yue Sun ${ }^{1,2}$, Lin Zhu ${ }^{1,2}$ and Dongchu Shu ${ }^{10}$ \\ 1 State Key Laboratory of Petroleum Resources and Prospecting, China University of Petroleum (Beijing), \\ Beijing 102249, China; ejeo33@163.com (Y.H.); sya@petrochina.com.cn (Y.S.); mingw930331@163.com (M.W.); \\ lixin_2686@126.com (X.L.); m15210011323@163.com (T.L.); sunny_cao1995@163.com (X.C.); \\ sykklt@163.com (Y.S.); alin0212@126.com (L.Z.) \\ 2 Unconventional Natural Gas Institute, China University of Petroleum (Beijing), Beijing 102249, China \\ 3 Unconventional Petroleum Collaborative Innovation Center, China University of Petroleum (Beijing), \\ Beijing 102249, China \\ 4 Research Institute of Petroleum Exploration and Development, Beijing 100083, China \\ 5 Energy and Geoscience Institute, University of Utah, Salt Lake City, UT 84108, USA; sjiang@egi.utah.edu \\ 6 School of Geoscience, Research Institute of Unconventional Oil \& Gas and Renewable Energy, China \\ University of Petroleum (East China), Qingdao 266480, China \\ 7 Key Laboratory of Strategy Evaluation for Shale Gas, Ministry of Land and Resources, Beijing 10083, China \\ 8 Jiangxi Provincial Natural Gas Company, Ltd., Nanchang 330000, China; weiweiliuedu@126.com \\ 9 Guangzhou Marine Geological Survey, Guangzhou 510075, China; 15652635334@163.com \\ 10 Zhejiang Oilfield Company, CNPC, Hangzhou 310023, China; shudc85@petrochina.com.cn \\ * Correspondence: zhenxuejiangedu@126.com (Z.J.); shandongzhangkun@126.com (K.Z.) \\ + These authors contributed equally to this work.
}

Received: 27 July 2018; Accepted: 23 October 2018; Published: 1 November 2018

\begin{abstract}
The effect of organic matter on hydrocarbon potential, storage space, and gas content of shale is well-known. Additionally, present-day content of sedimentary organic matter in shale is controlled by depositional and preservation processes. Therefore, a study of the enrichment mechanisms of sedimentary organic matter provides a scientific basis for the determination of favorable areas of shale gas. In this study the Upper Ordovician Xinkailing Fm. and the first member of the Lower Silurian Lishuwo Fm. were examined. Stratigraphic sequences were identified through conventional logs and elemental capture spectrum data. Oxygen isotope analysis was applied to recover paleotemperature of seawater in the study area. The excess silicon content was calculated and the origin of the silica was determined by the Fe-Al-Mn ternary plot. The enrichment mechanism of organic matter was analyzed by two aspects: redox conditions and paleoproductivity. As a result, the stratigraphic interval was divided into two 3rd-order sequences. Through oxygen isotope, the paleotemperature of seawater was $62.7-79.2{ }^{\circ} \mathrm{C}$, providing evidence of the development of hydrothermal activity. Analysis of excess siliceous minerals identified two siliceous mineral origins: terrigenous and hydrothermal. It also revealed an upwards decreasing tendency in hydrothermal activity intensity. Strong hydrothermal activity during the Late Ordovician, recognized as TST1, formed a weak-oxidizing to poor-oxygen environment with high paleoproductivity, which promoted organic matter enrichment. During the Late Ordovician to the Early Silurian, identified as RST1, TST2, and RST2, weakening hydrothermal activity caused the decline of paleoproductivity and increased oxidation of bottom waters, leading to a relative decrease of organic matter content in the shale. Therefore, favorable areas of shale gas accumulation in the Upper Ordovician and Lower
\end{abstract}


Silurian are determined stratigraphically as the TST1, with a high total organic carbonate content. Geographically, the hydrothermally-active area near the plate connection of the Yangtze and the Cathaysian is most favorable.

Keywords: enclosed environments; hydrothermal activity; excess siliceous minerals; paleoproductivity; redox environments

\section{Introduction}

Since 2000, the shale gas industry has achieved great success in the United States, thanks to new ideas and advanced technology [1-3]. Energy Information Administration (EIA) [4] data for 2016 show that the gross withdrawal of natural gas from shale gas wells in American was $16.58 \times 10^{9}$ cubic feet, accounting for $50.81 \%$ in the total gross withdrawal of $32.64 \times 10^{9}$ cubic feet. There is a huge resource of shale gas in China as well, and preliminary commercial development has begun in areas including Jiaoshiba, Weiyuan, Changning, Dingshan etc., starting in 2010 [5-10]. Identification of the most favorable stratigraphic intervals, both vertically and laterally, is urgent [11-13]. Organic matter, the source of shale gas generation, develops organic pores during thermal maturation, providing storage sites for generated gas. Interconnection of the pores provides permeability [14-18]. As such organic matter abundance is one of the key indicators of shale gas evaluation. The present-day total organic carbon (TOC) content in shale is largely influenced by thermal evolution and the original abundance of sedimentary organic matter [19,20], which means it is mainly controlled by depositional and preservation processes of organic matter under a certain thermal evaluation. Therefore, this paper is focused on the geological factors controlling the original abundance of sedimentary organic matter and the enrichment mechanism of sedimentary organic matter.

Stratigraphic sequence establishment is needed in the study of sedimentary environments. Classic sequence stratigraphy is based on clastic rocks on passive continental margins [21-27], and has reduced accuracy when it is applied to shale deposited in deep-water environments [28,29]. Thus, the classic theory incompletely suits the exploration and development of shale gas. In recent decades, large-scale exploration and development of shale gas is enhanced by new technology, providing new methods and data for the research on sequence stratigraphy of shale gas and mechanisms of organic matter deposition. For example, the maturity of elemental capture spectroscopy (ESC) allows the study of various elements in shale, making it possible to assess redox conditions of shale deposition.

Previous work has used oxidation-reduction indicators to determine sequences in deep-water environments. Chen et al. [30] identified sequence boundaries by way of U/Th, well logs, and lithology, and identified the Longmaxi Fm. as a 3rd-order sequence. Yuan et al. [31] and Wang et al. [32] used difference of elements accumulation in deposition processes, applying the indicators $\mathrm{Ca} /(\mathrm{Ca}+\mathrm{Fe})$ and $\mathrm{Ti} / \mathrm{Al}$ for the characterization of different sedimentary environments and changes in water depth. Zhang et al. [33-35] proposed a sequence division method for shale by lithology, well logging, and outcrop data, using $\mathrm{U} / \mathrm{Th}$ as the principle index, $\mathrm{Ca} /(\mathrm{Ca}+\mathrm{Fe})$ and $\mathrm{Ti} / \mathrm{Al}$ as supporting indices.

The study of Fleming and Revelle [36] indicates paleoproductivity is the main control on the organic matter enrichment. Pedersen and Calvert [37] demonstrated paleoproductivity to be the main control on the generation of the organic-rich shale. This finding led to a model that considered reducing bottom waters and paleoproductivity as the most important factors of organic matter enrichment [38]. In previous studies, the geochemical indices widely used for paleoproductivity are P, Ba [39-45], Ni, and $\mathrm{Cu}$ [46-52]. Additionally, the geochemical parameters commonly applied to redox conditions are mainly redox-sensitive metal elements and their ratios [46,51,53-56], such as $\mathrm{U} / \mathrm{Th}, \mathrm{V} /(\mathrm{V}+\mathrm{Ni}), \mathrm{V} / \mathrm{Cr}$, $\mathrm{Ni} / \mathrm{Co}$, and Mo [55,57-60]. Holdaway and Clayton [61] defined no-terrigenous siliceous minerals as excess silicon, and proposed a quantitative calculation method. In addition, based on large amount of statistics, Wedepohl [62], Adachi et al. [63], and Yamamoto [64] proposed an Al-Fe-Mn method to 
identify the genesis of excess silicon (hydrothermal or biologic origin) widely applied under pelagic settings [33-35,60,65]. All these techniques help to reveal the influence of sedimentary environments on organic matter enrichment.

In this paper, stratigraphic sequences are divided mainly by well logs and ECS data to form a sequence stratigraphic framework for the study area. Additionally, oxygen isotope was analyzed to recover paleotemperature of seawater and verify existence of hydrothermal activity. The existence of the excess silicon is determined, with its content calculated and origin confirmed by an Al-Fe-Mn ternary plot. The excess silicon content is applied to study the geological factors controlling the original abundance of sedimentary organic matter. Then, the mechanism of the organic matter enrichment is further analyzed and a model is proposed to explain the organic matter enrichment in shale of the Late Ordovician to the Early Silurian in the Lower Yangtze Region, South China.

\section{Geological Settings}

\subsection{Sedimentary and Stratigraphy}

According to previous research [33,34,66-68], well $X$ is located in the southern part of the Lower Yangtze, which is described as a deep-water shelf controlled by a foreland basin in the Late Ordovician and Early Silurian. The southern part of the Lower Yangtze generally transformed from shallow-water shelf into onshore and ancient land northwestwards, while the Cathaysia plate in the south changed dramatically from shallow-water shelf into and ancient land $[34,35,67,68]$. The location of Well $\mathrm{X}$ is near the connection of the Cathaysia and the Yangtze plates (Figure 1).

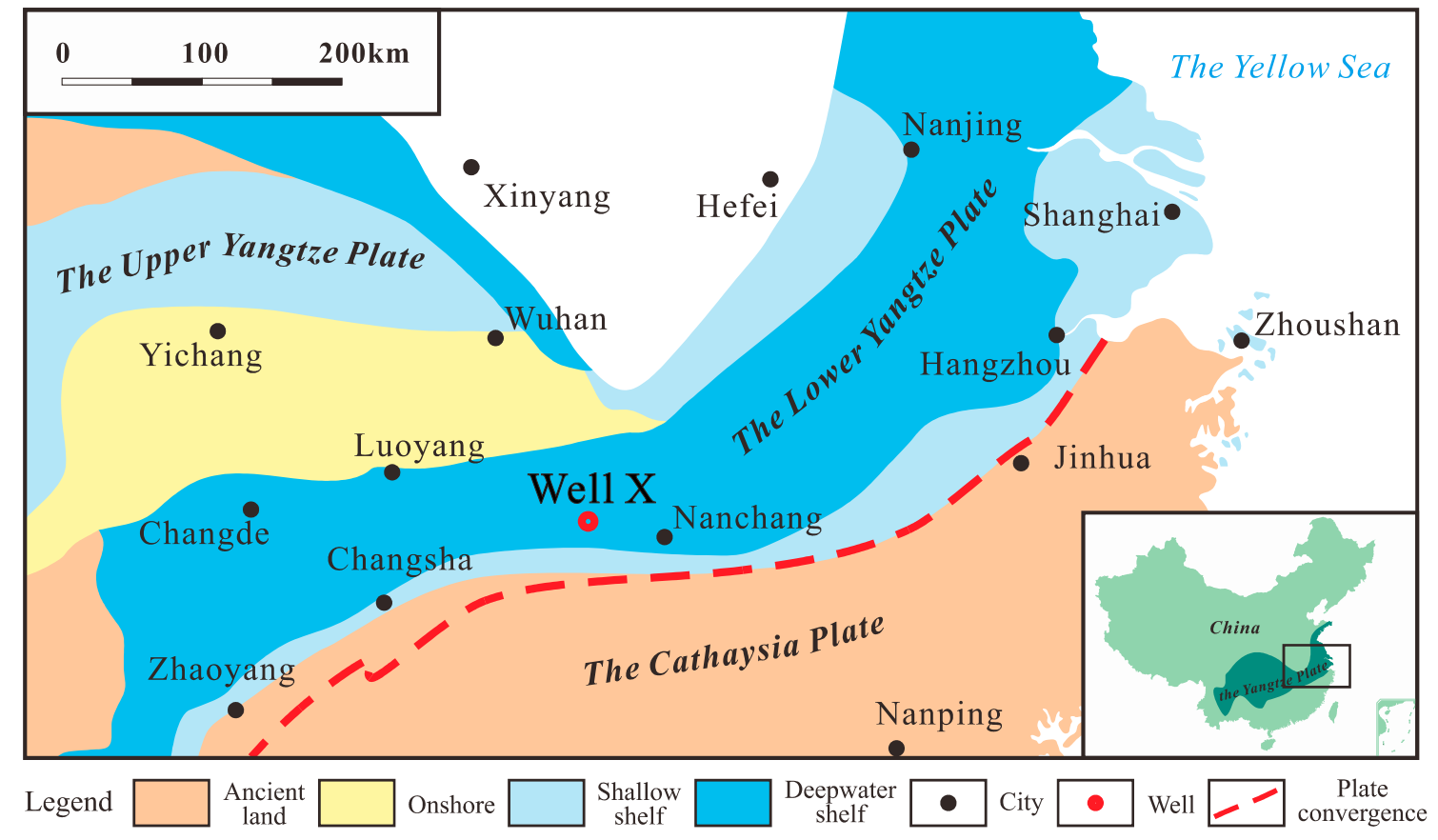

Figure 1. The map of the regional sedimentary characteristics of the Late Ordovician to the Early Silurian in the Lower Yangtze, South China. Samples were taken from Well X shown on the map.

The research interval is the Upper Ordovician Xinkailing Fm. and the first member of the Lower Silurian Lishuwo Fm., which is a shale stratum widely spread across the Yangtze plate. The lithology of the research interval is divided into two parts. The Xinkailing Fm. and the lower part of the first member of the Lishuwo Fm. are dominated by a combination of black siliceous shale and gray black calcareous shale. Shale, silty shale, and siltstone, grey green and yellow green in color, occur in the upper part of the first member of the Lishuwo Fm. 


\subsection{Tectonic Evolution}

The Yangtze and Cathaysia plates in southern China formed in the Early Mesoproterozoic and united to the South China plate in Middle and Late Neoproterozoic. Up to the early Paleozoic, the Yangtze plate and Cathaysia plate separated again under tension and an intracontinental basin, which is narrow and enclosed, formed in the study area [68-70]. The Lower Yangtze experienced a large-scale marine transgression in the Early Cambrian, which contributed to the extensive distribution of organic-rich shale in the Lower Cambrian. Its lithology is dominated by shale and silty shale. This was followed by a regression, causing the water body to become shallower and the lithology to gradually change to siltstone and sandstone [71]. The Yangtze and Cathaysia plates were under compression, resulting in more frequent plate activities and an intracontinental orogeny until the Ordovician [68-70]. The water body became even shallower, resulting in a transition in the lithology from a clastic rock depositional system into a carbonate sedimentary system. During the Late Ordovician and the Early Silurian, the Lower Yangtze region experienced another large scale of transgression, and this was when the organic-rich shale in the Xinkailing Fm. and the first member of the Lishuwo Fm. were deposited. Finally, the two plates were formally joined again to the Southern China plate at the end of the Silurian [69-71].

\section{Samples, Experiments, and Data Source}

Forty-two crushed samples from the Xinkailing Fm. and the first member of Lishuwo Fm. in Well $\mathrm{X}$ were tested for present-day TOC content using an OG-2000V analyzer (Guangzhou ZHIYUAN Electronics Co., Ltd., Guangzhou, China) (Table 1). Ninety-one drill cutting samples from the same interval were tested by an Axios-MAX (Malvern Panalytical, Malvern, UK), X-ray fluorescence spectrometer, to obtain the abundance of $\mathrm{Al}, \mathrm{Fe}, \mathrm{Mn}$, and $\mathrm{Ba}$ (Table 2).

Table 1. The sample numbers, formations and burial depths of the samples from Well $\mathrm{X}$ for total organic carbon (TOC) tests. See Figure 1 for the well location.

\begin{tabular}{ccccccccc}
\hline No. & Fm. & Depth/m & No. & Fm. & Depth/m & No. & Fm. & Depth/m \\
\hline 1 & Lishuwo & 1279.8 & 15 & Lishuwo & 1322.1 & 29 & Xinkailing & 1340.7 \\
2 & Lishuwo & 1282.5 & 16 & Lishuwo & 1323.9 & 30 & Xinkailing & 1341.2 \\
3 & Lishuwo & 1290.2 & 17 & Lishuwo & 1326.9 & 31 & Xinkailing & 1343.3 \\
4 & Lishuwo & 1294.8 & 18 & Lishuwo & 1328.7 & 32 & Xinkailing & 1343.7 \\
5 & Lishuwo & 1296.9 & 19 & Lishuwo & 1329.0 & 33 & Xinkailing & 1345.2 \\
6 & Lishuwo & 1298.9 & 20 & Lishuwo & 1330.3 & 34 & Xinkailing & 1345.9 \\
7 & Lishuwo & 1302.7 & 21 & Lishuwo & 1331.2 & 35 & Xinkailing & 1347.3 \\
8 & Lishuwo & 1304.3 & 22 & Lishuwo & 1332.0 & 36 & Xinkailing & 1347.5 \\
9 & Lishuwo & 1309.7 & 23 & Lishuwo & 1334.7 & 37 & Xinkailing & 1349.0 \\
10 & Lishuwo & 1312.7 & 24 & Lishuwo & 1335.9 & 38 & Xinkailing & 1349.8 \\
11 & Lishuwo & 1314.9 & 25 & Lishuwo & 1337.1 & 39 & Xinkailing & 1350.5 \\
12 & Lishuwo & 1317.1 & 26 & Lishuwo & 1338.0 & 40 & Xinkailing & 1351.4 \\
13 & Lishuwo & 1319.0 & 27 & Xinkailing & 1339.4 & 41 & Xinkailing & 1353.8 \\
14 & Lishuwo & 1320.4 & 28 & Xinkailing & 1339.7 & 42 & Xinkailing & 1357.3 \\
\hline
\end{tabular}

To calculate and analyze the data comprehensively, the data of ESC from Schlumberger were collected. Conventional well logs of gamma-ray (GR), acoustic velocity (AC), density (DEN), neutron porosity (CNL), $\mathrm{U}$ and Th sampled every $0.125 \mathrm{~m}$, provided element data for $\mathrm{Si}, \mathrm{Ca}, \mathrm{Fe}$, $\mathrm{Al}$, and Ti.

Two core samples from the Xingkailing Fm. and one core sample from Lishuwo Fm. in Well $X$ were selected for oxygen isotope analysis by mass spectrometer MAT-251EM (Thermo Fisher Scientific, Waltham, MA, USA) in Nanjing University. The information of samples is shown in Table 3. The samples were crushed to 200 mesh, calcined, removed of organic matter, and then soaked in $\mathrm{HCl}$ to remove siderite and other sulfides. The purified sample $\left(\mathrm{SiO}_{2}\right)$ was reacted with $\mathrm{BrF}_{5}$ at a constant 
temperature of $550{ }^{\circ} \mathrm{C}$ to form $\mathrm{SiF}_{4}$ gas. The purified $\mathrm{SiF}_{4}$ gas was obtained by liquid nitrogen cold trap and other purification processes. The mass spectrometer agrees with the international standard SMOW, and its analytical accuracy is $(+0.2 \%)$.

Table 2. The sample numbers, formations and burial depths of the samples from Well X for X-ray fluorescence spectrometer. See Figure 1 for the well location.

\begin{tabular}{|c|c|c|c|c|c|c|c|c|}
\hline No. & Fm. & Depth/m & No. & Fm. & Depth/m & No. & Fm. & Depth/m \\
\hline 1 & Lishuwo & 1284.91 & 32 & Lishuwo & 1301.60 & 63 & Lishuwo & 1338.56 \\
\hline 2 & Lishuwo & 1285.11 & 33 & Lishuwo & 1302.10 & 64 & Xinkailing & 1343.27 \\
\hline 3 & Lishuwo & 1285.21 & 34 & Lishuwo & 1302.55 & 65 & Xinkailing & 1343.78 \\
\hline 4 & Lishuwo & 1285.89 & 35 & Lishuwo & 1304.27 & 66 & Xinkailing & 1344.32 \\
\hline 5 & Lishuwo & 1285.91 & 36 & Lishuwo & 1304.93 & 67 & Xinkailing & 1344.90 \\
\hline 6 & Lishuwo & 1286.14 & 37 & Lishuwo & 1306.41 & 68 & Xinkailing & 1345.52 \\
\hline 7 & Lishuwo & 1286.44 & 38 & Lishuwo & 1310.39 & 69 & Xinkailing & 1346.08 \\
\hline 8 & Lishuwo & 1286.70 & 39 & Lishuwo & 1310.48 & 70 & Xinkailing & 1346.60 \\
\hline 9 & Lishuwo & 1286.80 & 40 & Lishuwo & 1320.41 & 71 & Xinkailing & 1347.05 \\
\hline 10 & Lishuwo & 1286.84 & 41 & Lishuwo & 1320.73 & 72 & Xinkailing & 1348.31 \\
\hline 11 & Lishuwo & 1290.04 & 42 & Lishuwo & 1320.79 & 73 & Xinkailing & 1349.54 \\
\hline 12 & Lishuwo & 1290.16 & 43 & Lishuwo & 1320.91 & 74 & Xinkailing & 1349.90 \\
\hline 13 & Lishuwo & 1290.32 & 44 & Lishuwo & 1320.98 & 75 & Xinkailing & 1350.28 \\
\hline 14 & Lishuwo & 1290.38 & 45 & Lishuwo & 1321.09 & 76 & Xinkailing & 1351.02 \\
\hline 15 & Lishuwo & 1290.54 & 46 & Lishuwo & 1321.61 & 77 & Xinkailing & 1351.27 \\
\hline 16 & Lishuwo & 1290.89 & 47 & Lishuwo & 1321.94 & 78 & Xinkailing & 1352.08 \\
\hline 17 & Lishuwo & 1290.96 & 48 & Lishuwo & 1322.44 & 79 & Xinkailing & 1353.27 \\
\hline 18 & Lishuwo & 1291.09 & 49 & Lishuwo & 1324.63 & 80 & Xinkailing & 1353.33 \\
\hline 19 & Lishuwo & 1291.26 & 50 & Lishuwo & 1325.43 & 81 & Xinkailing & 1354.30 \\
\hline 20 & Lishuwo & 1291.34 & 51 & Lishuwo & 1329.46 & 82 & Xinkailing & 1354.67 \\
\hline 21 & Lishuwo & 1291.54 & 52 & Lishuwo & 1330.03 & 83 & Xinkailing & 1354.70 \\
\hline 22 & Lishuwo & 1291.74 & 53 & Lishuwo & 1332.82 & 84 & Xinkailing & 1355.73 \\
\hline 23 & Lishuwo & 1292.00 & 54 & Lishuwo & 1333.73 & 85 & Xinkailing & 1356.30 \\
\hline 24 & Lishuwo & 1292.79 & 55 & Lishuwo & 1333.80 & 86 & Xinkailing & 1357.75 \\
\hline 25 & Lishuwo & 1292.80 & 56 & Lishuwo & 1334.42 & 87 & Xinkailing & 1358.10 \\
\hline 26 & Lishuwo & 1293.14 & 57 & Lishuwo & 1335.11 & 88 & Xinkailing & 1358.40 \\
\hline 27 & Lishuwo & 1295.15 & 58 & Lishuwo & 1335.86 & 89 & Xinkailing & 1359.04 \\
\hline 28 & Lishuwo & 1295.55 & 59 & Lishuwo & 1336.42 & 90 & Xinkailing & 1359.53 \\
\hline 29 & Lishuwo & 1298.18 & 60 & Lishuwo & 1336.95 & 91 & Xinkailing & 1359.93 \\
\hline 30 & Lishuwo & 1298.85 & 61 & Lishuwo & 1337.44 & & & \\
\hline 31 & Lishuwo & 1301.03 & 62 & Lishuwo & 1338.15 & & & \\
\hline
\end{tabular}

No.: sample number; Fm.: formation.

Table 3. The sample numbers, formations and burial depths of the samples from Well $\mathrm{X}$ for oxygen isotope experiments. See Figure 1 for the well location.

\begin{tabular}{ccc}
\hline No. & Fm. & Depth/m \\
\hline 1 & Xinkailing & 1358 \\
2 & Xingkailin & 1344 \\
3 & Lishuwo & 1327 \\
\hline
\end{tabular}

\section{Results and Discussion}

\subsection{Stratigraphic Sequence}

Sequence stratigraphy theory [24] has been widely applied to guiding conventional oil and gas exploration. However, due to the weak response of the deep-water environment to changes of sea level, it is difficult to identify the boundary between the low-stand and high-stand system tracts. While the T-R cycle, which emphasizes the depth changes of water body, dividing a sequence into a transgressive 
system tract (TST) and a regressive system (RST), is more suitable for the sedimentary characteristics of deep-water environments where shale deposited [72].

Uranium is easily reduced to precipitate uranium black, a uranium-rich ore, or to be adsorbed by other substances. Thorium is easily hydrolyzed in a weak alkaline solution and become an oxide or hydroxide precipitate [73]. Together, their ratios can indicate redox environments [58]. Generally speaking, its variation indicates the process of transgression and regression $[30,32,57,58,74,75]$. It is well-known that Ca responds to sedimentary process [76,77]. Due to the difference of migratory process of $\mathrm{Ca}$ and $\mathrm{Fe}$, Yuan et al. [31] and Wang et al. [32] provides evidence that there is a positive correlation between $\mathrm{Ca} /(\mathrm{Ca}+\mathrm{Fe})$ and salinity of the water body [31]. The decrease in $\mathrm{Ca} /(\mathrm{Ca}+\mathrm{Fe})$ reflects transgression $[31,32,76]$. $\mathrm{Al}$ and $\mathrm{Ti}$ are inactive in chemical weathering $[31,32,78]$. In pure argillaceous shale deposition, $\mathrm{Ti} / \mathrm{Al}$ can be used to determine distance from provenance as an indicator of shoreline migration [32]. As such, $\mathrm{Ti} / \mathrm{Al}$ values reflect transgression and regression indirectly $[32,76,78,79]$. Therefore, the above parameters can be used as markers for sequence stratigraphy in deep-water sediments lacking obvious lithology changes. In this paper, the sequence stratigraphy is identified by $\mathrm{U} / \mathrm{Th}$ primarily and by $\mathrm{Ca} /(\mathrm{Ca}+\mathrm{Fe})$ and $\mathrm{Ti} / \mathrm{Al}$ supportively.

As Figure 2 shows, U/Th tends to increase and then decrease in the Xinkailing Fm. and the first member of the Lishuwo Fm., including two smaller cycles of rises and falls. There are corresponding tendencies of decrease first and then increase in $\mathrm{Ca} /(\mathrm{Ca}+\mathrm{Fe})$ and $\mathrm{Ti} / \mathrm{Al}$, with two smaller ascending and descending cycles. According to the data from International Commission on Stratigraphy (ICS) [80], the duration of the Xinkailing Fm. and the first member of the Lishuwo Fm. is about 4.4 Ma (445.2-440.8 Ma). A 2nd-order sequence is about 10-25 Ma, and a 3rd-order sequence is about 1-3 Ma [81]. Using the trends of curves from well logs and ECS data, the Xinkailing Fm. and the first member of the Lishuwo Fm. is divided into two 3rd-order sequences, Seq.1 and Seq.2 (Figure 2). Seq.1 is composed of a long transgressive system tract (TST1) and short regressive system tract (RST1), while Seq. 2 contains a short transgressive system tract (TST2) and a long regressive system tract (RST2).

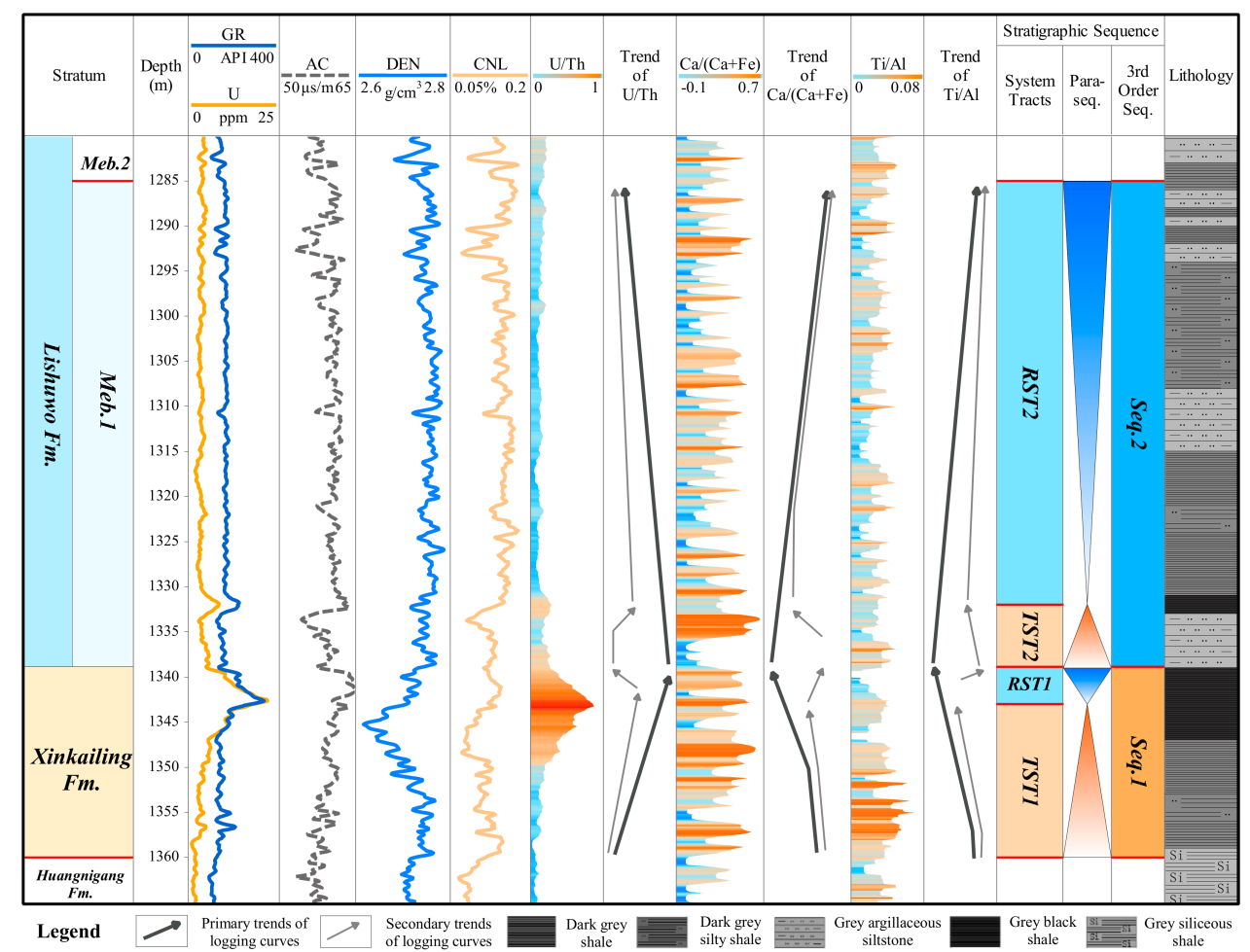

Figure 2. The stratigraphic sequence division of Xinkailing Fm. and the first member of the Lishuwo Fm. in Well X, the Lower Yangtze. See Figure 1 for the well location. GR = Gamma-ray log, AC = acoustic velocity $\log , \mathrm{DEN}=$ density $\log , \mathrm{CNL}=$ neutron $\log , \mathrm{U}=$ uranium, $\mathrm{Th}=$ thorium, $\mathrm{Ca}=$ calcium, $\mathrm{Fe}=$ iron, $\mathrm{Ti}=$ titanium, $\mathrm{Al}=$ aluminum . 


\subsection{Hydrothermal Activity}

\subsubsection{Oxygen Isotope Analysis}

The oxygen isotope of siliceous rocks can be used to calculate the temperature of the ancient sea [82]. The oxygen isotope method to obtain paleotemperature of seawater for siliceous rocks is shown in the following two equations.

$$
\begin{gathered}
\delta^{18} O_{(\text {shale })}-\delta^{18} O_{(\text {water })}=\frac{3.09 \times 10^{6}}{T^{2}}-3.29 \\
t=5.0-4.1 \times\left(\delta^{18} O_{(\text {shale })}-\delta^{18} O_{(\text {water })}-40\right)
\end{gathered}
$$

$\delta^{18} O_{(\text {shale })}$ is the oxygen isotope composition of the shale. $\delta^{18} O_{(\text {water })}$ is the oxygen isotope composition of the sedimentary medium (seawater). In Equation (1), $T$ is thermodynamic temperature of ancient seawater, $t$ is centigrade degree of ancient seawater. In the two equations above, the oxygen isotope composition of sedimentary medium is unknown, but previous studies have shown that the oxygen isotope composition of seawater has little change from ancient times to the present. Therefore, it is assumed that the oxygen isotope composition of ancient seawater is the same as that of present-day seawater, as $0[82,83]$.

According to the above hypothesis, paleotemperature of seawater in the Upper Ordovician-Lower Silurian in the study area calculated by Equation (1) was 62.7-77.1 ${ }^{\circ} \mathrm{C}$ (Table 4), and that calculated by Equation (2) is $70.2-79.2^{\circ} \mathrm{C}$. The content of Fe and $\mathrm{S}$ of the intervals is $4.9 \%$ and $0.7 \%$ respectively, relatively low when compared to other rock types. Furthermore, iron and sulfate reduction were not observed during the description of thin sections. Since the absence of minerals resulting from diagenetic precipitation in the thin section observation and the low content of Fe and S shown in the ECS data, this temperature was more likely to represent a depositional signal rather than a diagenetic process, which basically verity the existence of hydrothermal activity during the period.

Table 4. Oxygen isotope of the Upper Ordovician-Lower Silurian shale and sedimentary environment temperature calculated by empirical equations.

\begin{tabular}{cccc}
\hline No. & $\boldsymbol{\delta}^{\mathbf{1 8}} \mathbf{O} / \% 0$ & $\begin{array}{r}\text { Paleotemperature of Seawater } \\
\left({ }^{\circ} \mathbf{C}\right)(\text { by Equation }(\mathbf{1}))\end{array}$ & $\begin{array}{c}\text { Paleotemperature of Seawater } \\
\left({ }^{\circ} \mathbf{C}\right) \text { (by Equation (2)) }\end{array}$ \\
\hline 1 & 23.7 & 65.2 & 71.8 \\
2 & 21.9 & 77.1 & 79.2 \\
3 & 24.1 & 62.7 & 70.2 \\
\hline
\end{tabular}

\subsubsection{Excess Silicon Analysis}

To accurately analyze the enrichment mechanism of sedimentary organic matter in the shale of the Xinkailing Fm. and the first member of the Lishuwo Fm. in the Lower Yangtze, the concept of excess silicon is used. Siliceous mineral genesis can be divided into terrigenous clastic sediments deposited in normal conditions, and hydrothermal and biological origin, silica under special circumstances [84-87]. Excess silicon content $\left(S i_{e x}\right)$, which can be calculated by the following equation:

$$
S i_{e x}=S i_{s}-\left[\left(\frac{S i}{A l}\right)_{b g} \times A l_{s}\right]
$$

where, $S i_{S}$ is the silicon content of the samples; $A l_{S}$ is the aluminum content of the samples; $\left(\frac{S i}{A l}\right)_{b g}$ is equal to 3.11, the average of the ratio of silicon and aluminum in shales [62].

The excess siliceous mineral content of Xinkailing Fm. and the first member of the Lishuwo Fm. in Well X, calculated by Equation (3), reveals a range of 0-22.70\%. Si $i_{e x}$ in TST1 is relatively high and 
greater than $5 \%$ in most of the interval. During RST1, $S i_{e x}$ decreases. In TST2, $S i_{e x}$ declines continually. Until RST2, $S i_{e x}$ is less than $5 \%$ in most of the interval and even the excess siliceous minerals do not exist. Generally speaking, the excess siliceous mineral decreases upwards in the Xinkailing Fm. and the first member of the Lishuwo Fm., whose high-value sector is in TST1.

The measured values of the content of $\mathrm{Al}, \mathrm{Fe}$, and $\mathrm{Mn}$ were collected in the intervals containing excess siliceous minerals. The data points are plotted on a ternary in Figure 3, showing that all the points lie in the hydrothermal origin area. Due to the applicable environments of Al-Fe-Mn method, which is generally deep-water marine environments and influences of other possibilities such as circulation, weathering, stratification, and diagenetic process, alternative explanations of this result need to be discussed. According to regional geological settings, the study area is located in a narrow and long intracontinental sea which is relatively enclosed and was far away from the coastline. Its communication with the open ocean kept slowly but constantly [68-70]. While magmatism leading to hydrothermal activity occurred frequently during the sedimentary period [69-71], which makes it a relatively higher possibility that the siliceous minerals of these intervals were derived of hydrothermal activity.

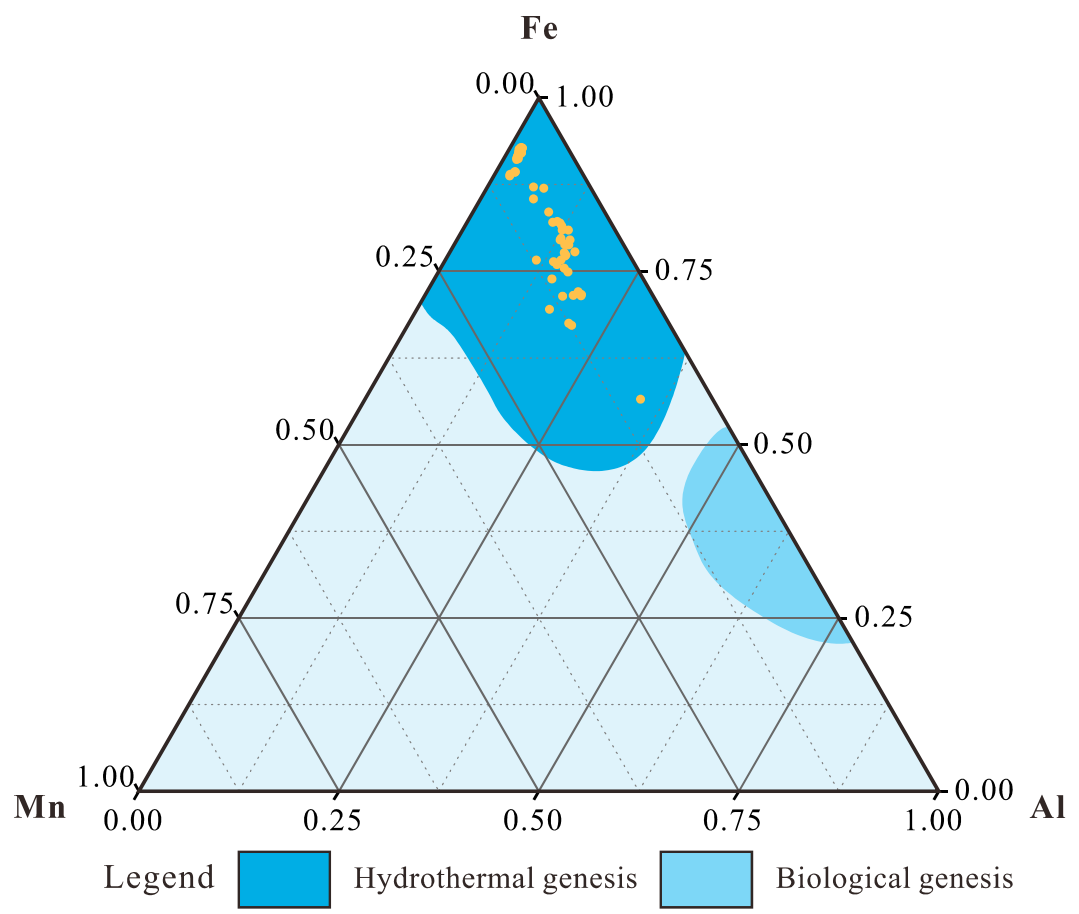

Figure 3. The genesis analysis of the excess silicon of the Xinkailing Fm. and the first member of the Lishuwo Fm. in Well X, the Lower Yangtze. See Figure 1 for the well location.

\subsubsection{Intensity of Hydrothermal Activity}

Through the studies above, it indicates that $S i_{e x}$ in the Xinkailing Fm. and the first member of the Lishuwo Fm. in study area were derived of hydrothermal activity. Therefore, in the Xinkailing Fm. and the first member of the Lishuwo Fm. in the Lower Yangtze, $S i_{e x}$ generally stands for hydrothermal silicon, making it a relatively reliable indicator of regional hydrothermal activity intensity, which may not be applicable in other areas where biogenic silicon dominants.

In this paper, the intervals with $S i_{e x}$ of $0-5 \%$ are defined to be a weak sector of hydrothermal activity, $5-10 \%$ as a relatively weak sector, $10-15 \%$ as a relatively strong sector, and $15-20 \%$ as a strong sector. The results are presented in Figure 4. It shows that in the Xinkailing Fm. and the first member of the Lishuwo Fm. in the Lower Yangtze, the hydrothermal activity intensity experienced was the strongest in TST1, and then weakened upwards from RST1 and TST2 to RST2. 


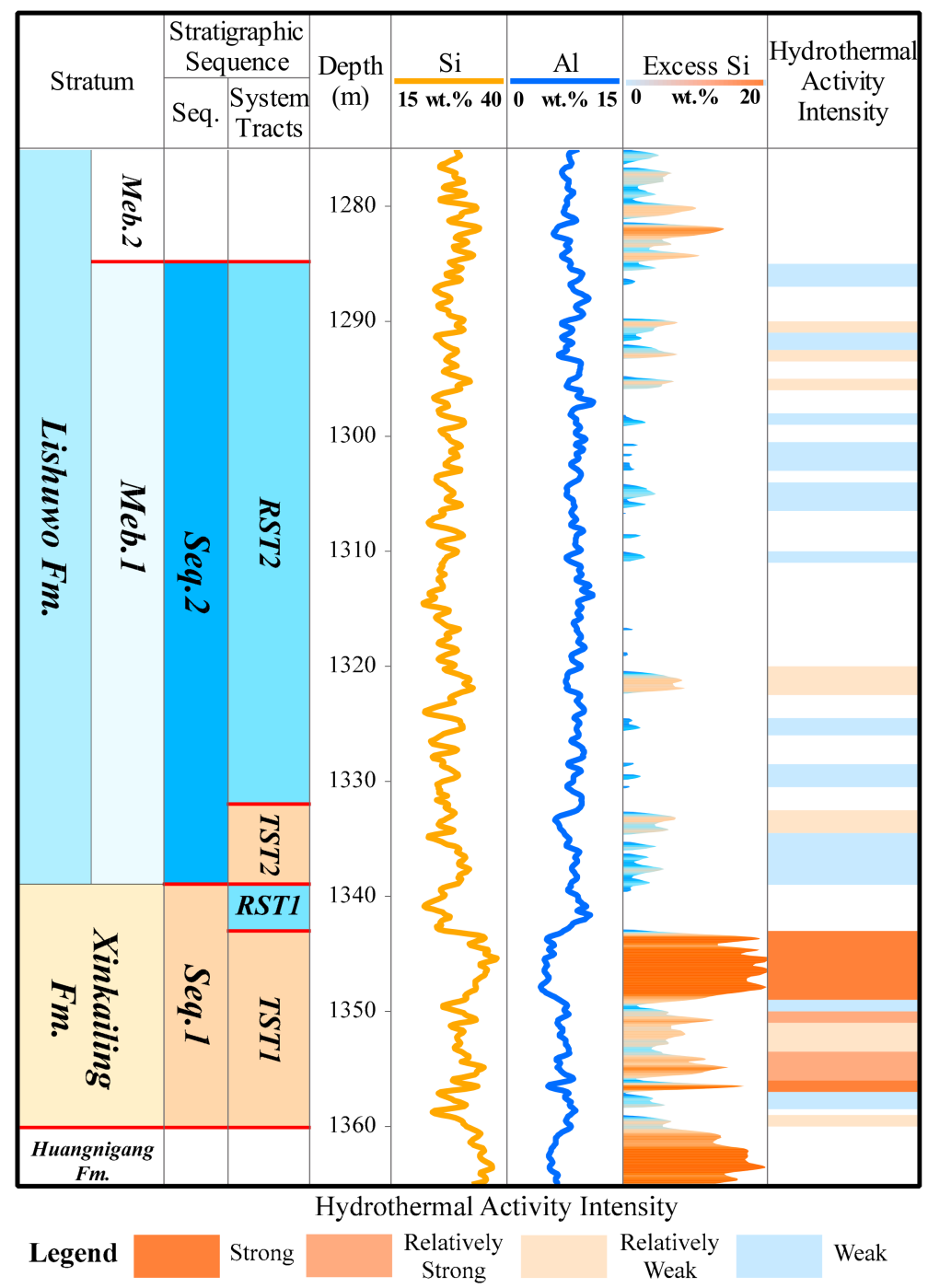

Figure 4. The analysis of hydrothermal activity intensity of Xinkailing Fm. and the first member of the Lishuwo Fm. in Well X, the Lower Yangtze. See Figure 1 for the well location. Al = aluminum, $\mathrm{Si}=$ silicon.

\subsection{Mechanism of Organic Matter Enrichment}

According to previous work [88], the siliceous minerals from the organic-rich shale are biogenic in the Upper Ordovician Wufeng Fm. and the bottom of the Lower Silurian Longmaxi Fm. in the Sichuan basin. From this, it is clear that the siliceous minerals of the Upper Ordovician-Lower Silurian in the Lower Yangtze region are not only biogenic (Wufeng-Longmaxi Shale) but of hydrothermal origin (the Xinkailing-Lishuwo Shale). This makes the Upper Ordovician-Lower Silurian a good candidate to explore the effect of hydrothermal activity on organic matter enrichment.

Besides controlling the accumulation of siliceous minerals in shale, there are two ways for hydrothermal activity to influence the abundance of sedimentary organic matter, by the control of redox environments and paleoproductivity.

\subsubsection{Redox Environments}

Sun [89] and Sun et al. [90] and Zhang et al. [91] demonstrated that reduced hydrothermal fluids can create an anoxic environment in the bottom waters where hydrothermal fluid is introduced, thus promoting the preservation of organic matter. 
The index of $\mathrm{U} / \mathrm{Th}$ is widely used to determine redox conditions and applied to the study of sedimentary environments of shale gas [58]. In this paper, ECS data of $U$ and Th was used, with samples being collected every $0.125 \mathrm{~m}$, making the trend changes of redox conditions obvious when observed. Value greater than 1.25 usually reflects anoxic environments, $0.75-1.25$ reflect poor-oxygen environments and less than 0.75 reflect oxidizing environments [58].

As presented in Figure 5, the content of hydrothermal siliceous minerals is greater than $5 \%$ in most intervals of TST1, which reveals a hydrothermal activity intensity reaching relatively strong. Furthermore, the U/Th is $0.5-1$ in TST1, indicating weak oxidizing to poor-oxygen environments. Therefore, the hydrothermal activity weakened upwards gradually during RST1. During RST2, siliceous minerals are mainly terrigenous, with hydrothermal siliceous minerals being less than 5\%, or nonexistent. In this time, $\mathrm{U} / \mathrm{Th}$ is $0-0.25$, corresponding to strong oxidizing environments.

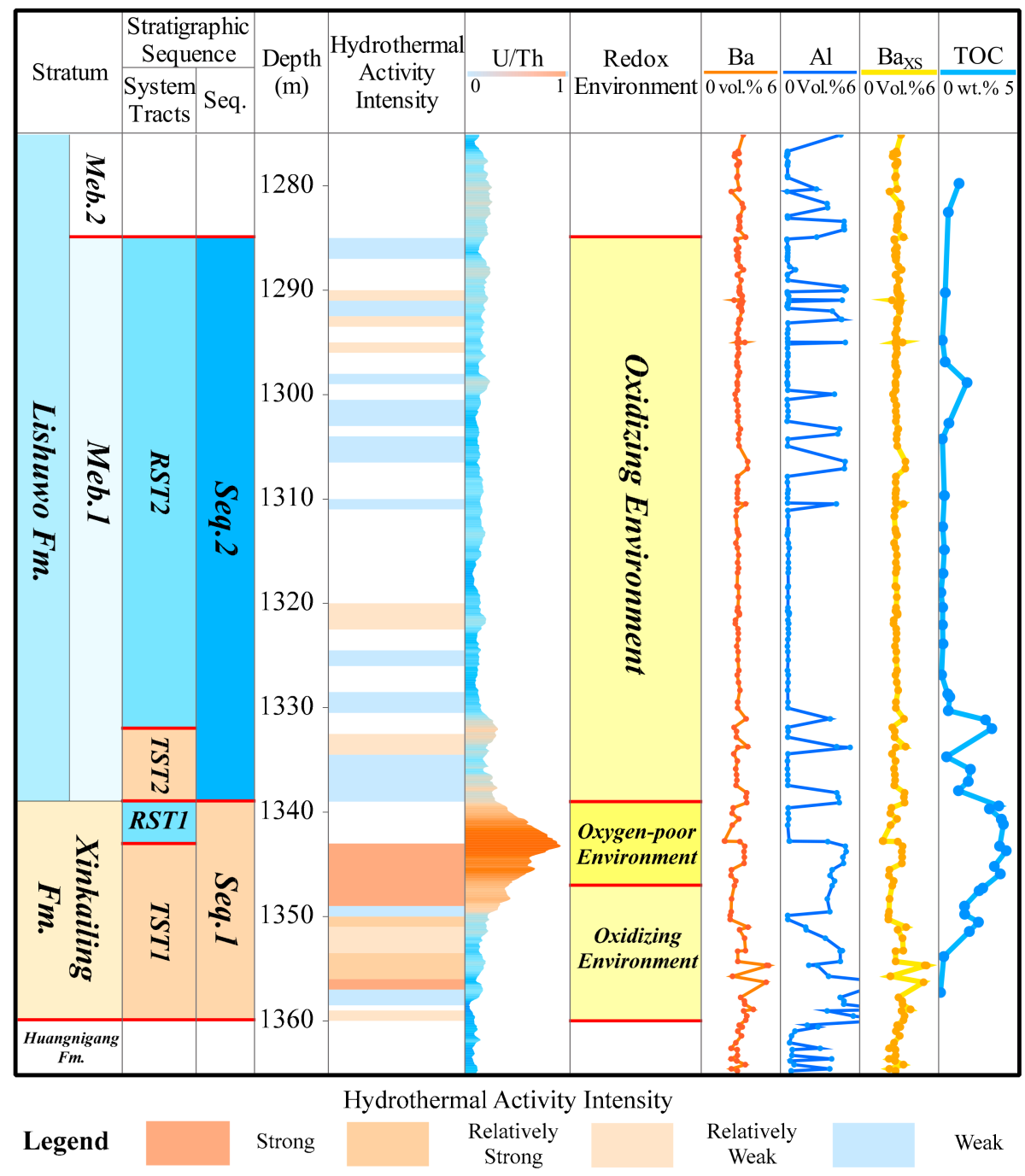

Figure 5. The influence of hydrothermal activity on organic matter enrichment of Xinkailing Fm. and the first member of the Lishuwo Fm. in Well X, the Lower Yangtze. See Figure 1 for the well location.

\subsubsection{Paleoproductivity}

Paleoproductivity could be closely connected to hydrothermal activity in the areas where hydrothermal activity exists. Through the study of Halbach et al. [92] on hydrothermal activity in the Fuji basin, it is seen that, compared to the normal surface layer of the water body, paleoproductivity is 1-3 orders of magnitudes higher in biomass in hydrothermally-active areas. The hydrothermal fluids carry with a large mass of nutrients necessary for marine organisms, such as Si, N, P, Fe, and Zn. Thus, 
which promote the growth of organisms $[93,94]$. This results in a large number of organisms being deposited on the basin bottom, resulting in organic matter enrichment in source rocks.

Barium is often used to reflect paleoproductivity. Trace elements in rocks consist of two parts, terrestrial and authigenic. Only the authigenic components indicate the characteristics of paleo sedimentary environments. Biological barium (excess barium, $B a_{X S}$ ) is used as an indicator of paleoproductivity, whose content is obtained from total barium content subtracting estimated content of terrigenous barium [39]. The content of $B a_{X S}$ is accessible by the following equation:

$$
B a_{X S}=B a_{S}-A l_{S} \times\left(\frac{B a}{A l}\right)_{P A A S}
$$

where, $B a_{s}$ is the total barium content of samples; $A l_{s}$ is the total aluminum content of samples; $\left(\frac{B a}{A l}\right)_{P A A S}$ is a constant of 0.0077 , the ratio of barium and aluminum of post-Archean Australian shale [95].

$B a_{X S}$ content of the Xinkailing Fm. and the first member of the Lishuwo Fm. in Well X is calculated by Equation (4), as shown in Figure 5. It revealed that during TST1, the content of hydrothermal siliceous minerals is high, reflecting strong hydrothermal activity. $B a_{X S}$ is higher in TST 1 , than in RST1, TST2 and RST2, which experienced a relatively weaker hydrothermal activity, indicating that there is a greater paleoproductivity in TST1.

Accordingly, it can be said, it is found out that the hydrothermal activity in the early Late Ordovician created a high-productive water body and environments of weak-oxidizing to poor-oxygen, which promoted the deposition of organic-rich shale in TST1 with TOC content of 2-4\% (Figure 5). A decrease of hydrothermal activity intensity in the Late Ordovician-Early Silurian, resulted in weakening paleoproductivity and water oxidizability increased accordingly. As a result, in shale deposited during RST1, TST2, and RST2, had decreased TOC content of $2 \%$, or less, in most parts of the interval (Figure 5).

\subsubsection{Model of Regional Organic Matter Enrichment}

In the study above, in this area, the effect of hydrothermal activity distinguished from other controlling factors of organic matter enrichment and it is investigated one of the key drivers of the regional enrichment of sedimentary organic matter. The strong hydrothermal activity of the Xinkailing $\mathrm{Fm}$. and the first member of the Lishuwo Fm. in the Lower Yangtze is related to the magmatism caused by the active plate movements between the Yangtze and Cathaysia plates in the Late Ordovician and the Early Silurian $[96,97]$.

In TST1 of the Late Ordovician, there are frequent plate motions between the Yangtze and Cathaysia plates, bringing a source of hydrothermal fluids to the junction of the plates. This caused an increase in nutrient levels leading to higher paleoproductivity and reduction of bottom waters, which enhanced the preservation of organic matter and deposition of the organic-rich shale during TST1 (Figure 6a). During RST1-RST2 in the Late Ordovician and the Early Silurian, the decreased plate movements reduced the intensity of hydrothermal activity, which decreased paleoproductivity and changed the redox environments into strong oxidizing environments. In addition, the terrigenous clay minerals and siliceous clasts are increased, forming a shale interval in RST1, TST2, and RST2, which contains a small amount of hydrothermal siliceous minerals and relatively lower TOC (Figure 6b).

We demonstrate that hydrothermal activity controls the redox environments of bottom waters and the paleoproductivity of surface layer of water, consequently affecting the regional enrichment of sedimentary organic matter and the present-day TOC content in shale. This indicates that in the Upper Ordovician and Lower Silurian in Lower Yangtze, the favorable stratigraphic interval is the TST1 with a relatively higher TOC. Areal-ly, the favorable area is the hydrothermally-active area, which is located near the connection of the plates, the Yangtze and the Cathaysia. 


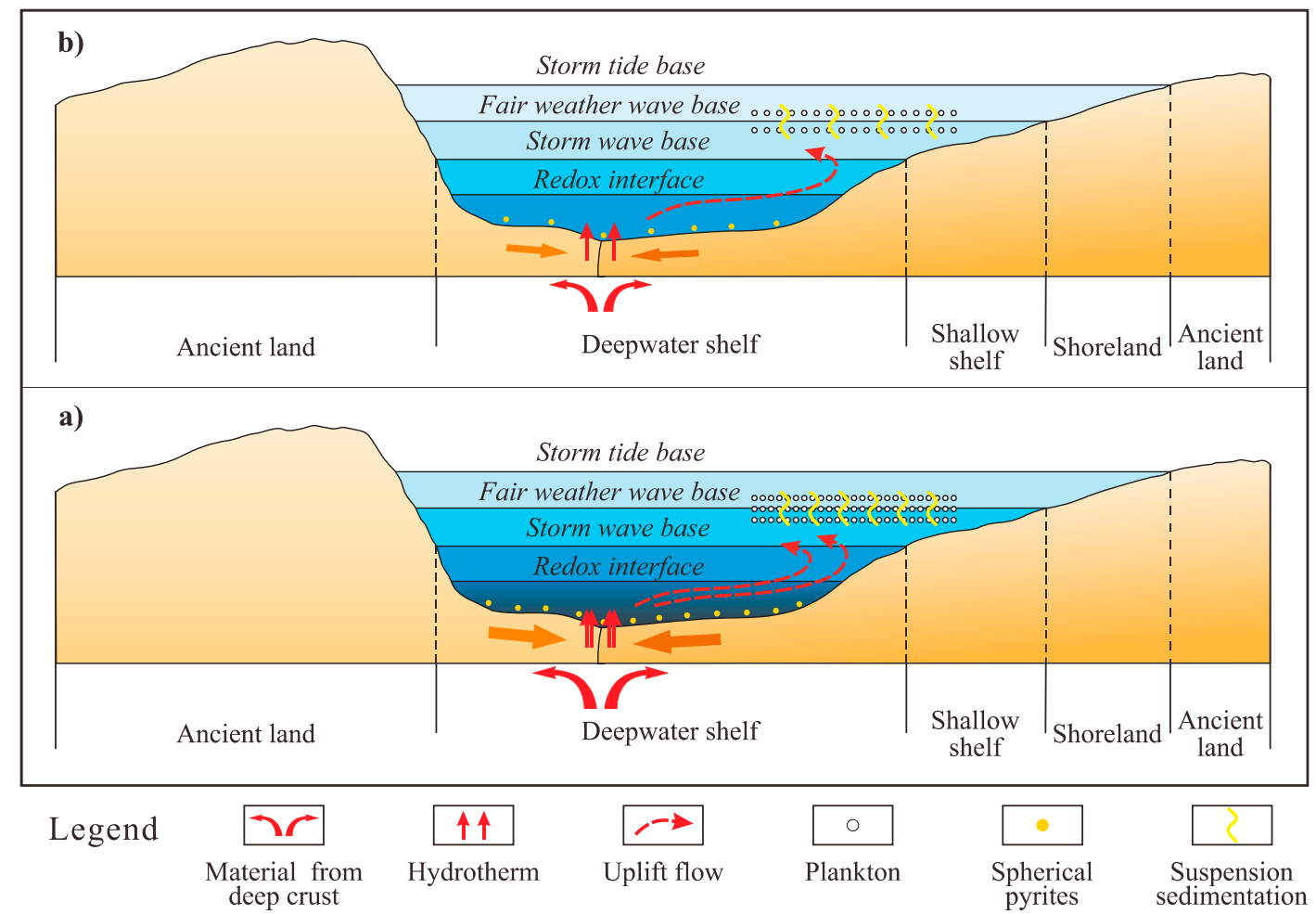

Figure 6. The model of organic matter enrichment in Well X, the Lower Yangtze. (a) In TST1 of the Late Ordovician; (b) In RST1, TST2, and RST2 of the Late Ordovician and the Early Silurian. See Figure 1 for the well location.

\section{Conclusions}

Due to the inapplicability of the classic sequence stratigraphy for the deep-water sediments and the significance of studying sedimentary environments of organic-rich shale, this paper focuses on the Upper Ordovician Xinkailing Fm. and the first member of the Lower Silurian Lishuwo Fm. Oxygen isotope analysis was applied to recover the paleotempreture of seawater. Well logs and ECS data are used to obtain the content of excess silicon and to determine the siliceous minerals' origin using an Al-Fe-Mn ternary diagram. Through these evidences basically proved the existence of hydrothermal activity. Afterwards, the enrichment mechanism of organic matter is analyzed by two aspects: redox environments and paleoproductivity. These analysis lead to the following conclusions.

1. Two 3rd-order sequences are identified in the Xinkailing Fm. and the first member of the Lishuwo Fm., when the paleotemperature of seawater was $62.7-79.2^{\circ} \mathrm{C}$, verifying the existence of hydrothermal activity. Within these units, siliceous minerals are terrigenous and hydrothermal, and the intensity of hydrothermal activity decreases upwards, being strongest during TST1.

2. Hydrothermal activity promotes paleoproductivity and reduces bottom waters, which are favorable for the preservation of organic matter. In the Late Ordovician, the active hydrothermal activity promotoed high paleoproductivity and weak-oxidizing to poor-oxygen environments and resulted in the deposition of organic-rich shale during TST1. Subsequently, hydrothermal activity weakened during RST1, TST2, and RST2, paleoproductivity decreased and oxidation increased, leading to a relatively lower TOC in the shale of these intervals.

3. In the Upper Ordovician and Lower Silurian in Lower Yangtze, the stratigraphically favorable interval is TST1, which has a relatively higher TOC. Geographically, the favorable area is an active area of hydrothermal activity located near the connection of the plates, the Yangtze and the Cathaysia. 
However, as we know, except for hydrothermal activity, there are factors including ocean circulation, chemical weathering, terrestrial runoff, and water body stratification that may have influences on organic matter enrichment in different situations. Also, iron and sulfate reduction resulting from diagenetic processes may cause an inaccurate result of Al-Fe-Mn analysis. Even though it is based on experimental data and previous geological settings this study demonstrated hydrothermal activity is one of the key controlling factors of regional organic matter enrichment, the possibilities of other alternative drivers could not be completely excluded. To clarify the whole process and all the details of organic matter enrichment in the study area, more related research still remains to be done.

Author Contributions: Conceptualization: Y.H. and K.Z.; Data curation: X.C., Y.S., and L.Z.; Formal analysis: Y.H., X.X., and T.L.; Methodology: K.Z. and X.L.; Project administration: Z.J.; Resources: W.L. and D.S.; Supervision: S.J., Z.J., C.J., and Y.S.; Writing (original draft): Y.H.; Writing (review and editing): K.Z., M.W. and Y.H.

Funding: This research is supported by National Science and Technology Major Project (No. 2017ZX05035-002), the Science Foundation of the Ministry of Land and Resources of China (No. 12120114046701), the National Natural Science Foundation of China (No. 41472112 and No. 41728004) and open fund from Sinopec Key Laboratory of Shale Oil/Gas Exploration and Production Technology.

Acknowledgments: Thanks to all the financings supporting the research, which are the National Science and Technology Major Project, the Science Foundation of the Ministry of Land and Resources of China, the National Natural Science Foundation of China and Sinopec Key Laboratory of Shale Oil/Gas Exploration and Production Technology. Additionally, thanks to all co-authors who worked with me through the whole research. Last but not least, much thanks to all the reviewers and the editor's office for their critical comments, constructive suggestions and distinguished work.

Conflicts of Interest: The authors declare no conflict of interest.

\section{References}

1. Warlick, D.N. Gas Shale and CBM Development in North America. Oil Gas Financ. J. 2006, 3, 1-5.

2. John, B.C. Fractured Shale-Gas Systems. AAPG Bull. 2002, 86, 1921-1938.

3. Montgomery, S.L.; Jarvie, D.M.; Bowker, K.A.; Pollastro, R.M. Mississippian Barnett Shale, Fort Worth basin, north-central Texas: Gas-shale play with multi-trillion cubic foot potential. AAPG Bull. 2005, 89, 155-175. [CrossRef]

4. U.S. Energy Information Administration (EIA) Homepage. Available online: http://www.eia.gov/ (accessed on 10 May 2018).

5. Chen, L.; Jiang, Z.; Liu, K.; Tan, J.; Gao, F.; Wang, P. Pore structure characterization for organic-rich Lower Silurian shale in the Upper Yangtze Platform, South China: A possible mechanism for pore development. J. Nat. Gas Sci. Eng. 2017, 46, 1-15. [CrossRef]

6. Chen, L.; Jiang, Z.; Liu, K.; Wang, P.; Ji, W.; Gao, F.; Li, P.; Hu, T.; Zhang, B.; Huang, H. Effect of lithofacies on gas storage capacity of marine and continental shales in the Sichuan Basin, China. J. Nat. Gas Sci. Eng. 2016, 36, 773-785. [CrossRef]

7. Dong, D.; Wang, Y.; Li, X.; Zou, C.; Guan, Q.; Zhang, C.; Huang, J.; Wang, S.; Wang, H.; Liu, H.; et al. Breakthrough and prospect of shale gas exploration and development in China. Nat. Gas Ind. 2016, 3, 12-26. (In Chinese) [CrossRef]

8. Guo, T. Key geological issues and main controls on accumulation and enrichment of Chinese shale gas. Pet. Explor. Dev. 2016, 43, 349-359. (In Chinese) [CrossRef]

9. Guo, X.; Hu, D.; Wei, Z.; Li, Y.; Wei, X.; Company, S.E. Discovery and exploration of Fuling shale gas field. China Pet. Explor. 2016, 21, 24-37. (In Chinese)

10. Wei, X.; Zhao, Z.; Wang, Q.; Liu, Z.; Zhou, M.; Zhang, H. Comprehensive Evaluation of Geological Conditions of the Shale Gas in Upper Ordovician Wufeng Formation-Lower Silurian Longmaxi Formation in Dingshan Area, Qijiang, Southeastern Sichuan. Geol. Rev. 2017, 63, 153-164. (In Chinese)

11. Liu, Q.; Tao, L.; Zhu, H.; Lei, Z.; Jiang, S.; McLennan, J.D. Macroscale Mechanical and Microscale Structural Changes in Chinese Wufeng Shale with Supercritical Carbon Dioxide Fracturing. SPE J. 2018, 23, 691-703. [CrossRef] 
12. Zhu, H.Y.; Jin, X.C.; Guo, J.C.; An, F.C.; Wang, Y.H.; Lai, X.D. Coupled flow, stress and damage modelling of interactions between hydraulic fractures and natural fractures in shale gas reservoirs. Int. J. Oil Gas Coal Technol. 2016, 13, 359-390. [CrossRef]

13. Zhu, H.; Deng, J.; Jin, X.; Hu, L.; Luo, B. Hydraulic Fracture Initiation and Propagation from Wellbore with Oriented Perforation. Rock Mech. Rock Eng. 2015, 48, 585-601. [CrossRef]

14. Ji, W.; Song, Y.; Jiang, Z.; Meng, M.; Liu, Q.; Chen, L.; Wang, P.; Gao, F.; Huang, H. Fractal characteristics of nano-pores in the Lower Silurian Longmaxi shales from the Upper Yangtze Platform, South China. Mar. Pet. Geol. 2016, 78, 88-98. [CrossRef]

15. Ji, W.; Song, Y.; Jiang, Z.; Wang, X.; Bai, Y.; Xing, J. Geological controls and estimation algorithms of lacustrine shale gas adsorption capacity: A case study of the Triassic strata in the southeastern Ordos Basin, China. Int. J. Coal Geol. 2014, 134-135, 61-73. [CrossRef]

16. Tang, X.; Jiang, Z.; Li, Z.; Gao, Z.; Bai, Y.; Zhao, S.; Feng, J. The effect of the variation in material composition on the heterogeneous pore structure of high-maturity shale of the Silurian Longmaxi formation in the southeastern Sichuan Basin, China. J. Nat. Gas Sci. Eng. 2015, 23, 464-473. [CrossRef]

17. Tang, X.L.; Jiang, Z.X.; Jiang, S.; Cheng, L.J.; Zhang, Y. Characteristics and origin of in-situ gas desorption of the Cambrian Shuijingtuo Formation shale gas reservoir in the Sichuan Basin, China. Fuel 2017, 187, $285-295$. [CrossRef]

18. Tang, X.L.; Jiang, Z.X.; Jiang, S.; Wang, P.F.; Xiang, C.F. Effect of Organic Matter and Maturity on Pore Size Distribution and Gas Storage Capacity in High-Mature to Post-Mature Shales. Energy Fuels 2016, 30, 8985-8996. [CrossRef]

19. Wang, P.; Jiang, Z.; Chen, L.; Yin, L.; Li, Z.; Zhang, C.; Tang, X.; Wang, G. Pore structure characterization for the Longmaxi and Niutitang shales in the Upper Yangtze Platform, South China: Evidence from focused ion beam-He ion microscopy, nano-computerized tomography and gas adsorption analysis. Mar. Pet. Geol. 2016, 77, 1323-1337. [CrossRef]

20. Wang, P.; Jiang, Z.; Ji, W.; Zhang, C.; Yuan, Y.; Chen, L.; Yin, L. Heterogeneity of intergranular, intraparticle and organic pores in Longmaxi shale in Sichuan Basin, South China: Evidence from SEM digital images and fractal and multifractal geometries. Mar. Pet. Geol. 2016, 72, 122-138. [CrossRef]

21. Catuneanu, O. Sequence stratigraphy of clastic systems: Concepts, merits, and pitfalls. J. Afr. Earth Sci. 2002, 35, 1-43. [CrossRef]

22. Jiang, S.; Henriksen, S.; Wang, H.; Lu, Y.; Ren, J.; Cai, D.; Feng, Y.; Weimer, P. Sequencestratigraphic architectures and sand-body distribution in Cenozoic rifted lacustrine basins, east ChinaSequence-Stratigraphic Architecture of Lacustrine Basins in East China. AAPG Bull. 2013, 97, 1447-1475. [CrossRef]

23. Lash, G.; Engelder, T. Thickness trends and sequence stratigraphy of the Middle Devonian Marcellus Formation, Appalachian Basin: Implications for Acadian foreland basin evolution. AAPG Bull. 2011, 95, 61-103. [CrossRef]

24. Vail, P.K.; Mitchum, R.M.; Todd, R.G.; Widmier, J.M.; Thompson, S.; Bubb, J.N.; Hatfield, W.G. Seismic Stratigraphy-applications to Hydrocarbon Exploration. In AAPG Memoir 26; Payton, C.E., Ed.; American Association of Petroleum Geologists: Tulsa, OK, USA, 1977; pp. 49-62.

25. Van Wagoner, J.C.; Van Mitchum, R.M.; Campion, K.; Rahmanian, V.D. Silicklastic Sequence Stratigraphy in Well Logs, Cores and Outcrops. In AAPG Methods in Exploration Series 7; Van Wagoner, J.C., Mitchum, R.M., Campion, K.M., Rahmanian, V.D., Eds.; American Association of Petroleum Geologists: Tulsa, OK, USA, 1990; pp. 1-63.

26. Weimer, P.; Varnai, P.; Budhijanto, F.M.; Acosta, Z.M.; Martinez, R.E.; Navarro, A.F.; Rowan, M.; McBride, B.C.; Villamil, T.; Arango, C.; et al. Sequence stratigraphy of Pliocene and Pleistocene turbidite systems, northern Green Canyon and Ewing Bank (offshore Louisiana), northern Gulf of Mexico. AAPG Bull. 1998, 82, 918-960.

27. Bohacs, K.; Lazar, R. Sequence stratigraphy in fine-grained rocks at the field to flow-unit scale: Insights for correlation, mapping, and genetic controls. In Proceedings of the Applied Geoscience Conference on US Gulf Region Mudstones as Unconventional Gas/Oil Reservoirs; Houston Geological Society: Houston, TX, USA, 2010.

28. Almon, W.; Dawson, W.C.; Sutton, S.; Ethridge, F.G.; Castelblanco, B. Sequence stratigraphy, facies variation and petrophysical properties in deepwater shales, Upper Cretaceous Lewis Shale, south-central Wyoming. Gulf Coast Assoc. Geol. Soc. Trans. 2002, 52, 1041-1053. 
29. Hemmesch, N.T.; Harris, N.B.; Mnich, C.A.; Selby, D. A sequence-stratigraphic framework for the Upper Devonian Woodford Shale, Permian Basin, west Texas. AAPG Bull. 2014, 98, 23-47. [CrossRef]

30. Chen, L.; Lu, Y.; Jiang, S.; Li, J.; Guo, T.; Luo, C.; Xing, F. Sequence stratigraphy and its application in marine shale gas exploration: A case study of the Lower Silurian Longmaxi Formation in the Jiaoshiba shale gas field and its adjacent area in southeast Sichuan Basin, SW China. J. Nat. Gas Sci. Eng. 2015, 27, 410-423. [CrossRef]

31. Yuan, Z.G. Using elemental capture spectroscopy (ECS) data to study depositional environment. Nucl. Electron. Detect. Technol. 2005, 25, 347-352. (In Chinese)

32. Wang, T.; Yang, K.; Xiong, L.; Shi, H.; Zhang, Q.; Wei, L.; He, X. Shale sequence stratigraphy of Wufeng-Longmaxi Formation in southern Sichuan and their control on reservoirs. Acta Pet. Sin. 2015, 36, 915-925. (In Chinese)

33. Zhang, K.; Jiang, Z.; Xie, X.; Gao, Z.; Liu, T.; Yin, L.; Jia, C.; Song, Y.; Shan, C.A.; Wu, Y.; et al. Lateral Percolation and Its Effect on Shale Gas Accumulation on the Basis of Complex Tectonic Background. Geofluids 2018, 2018, 5195469. [CrossRef]

34. Zhang, K.; Jiang, Z.; Yin, L.; Gao, Z.; Wang, P.; Song, Y.; Jia, C.; Liu, W.; Liu, T.; Xie, X.; et al. Controlling functions of hydrothermal activity to shale gas content-taking lower Cambrian in Xiuwu Basin as an example. Mar. Pet. Geol. 2017, 85, 177-193. [CrossRef]

35. Zhang, K.; Li, Z.; Jiang, S.; Jiang, Z.; Wen, M.; Jia, C.; Song, Y.; Liu, W.; Huang, Y.; Xie, X.; et al. Comparative Analysis of the Siliceous Source and Organic Matter Enrichment Mechanism of the Upper Ordovician-Lower Silurian Shale in the Upper-Lower Yangtze Area. Minerals 2018, 8, 283. [CrossRef]

36. Fleming, R.H.; Revelle, R. Physical Processes in the Ocean1. In Recent Marine Sediments; Trask, P.D., Ed.; SEPM Society for Sedimentary Geology: Broken Arrow, OK, USA, 1955; Available online: https://pubs. geoscienceworld.org/books/book/1121/chapter/10552931/physical-processes-in-the-ocean1 (accessed on 29 October 2018).

37. Pedersen, T.F.; Calvert, S.E. Anoxia vs. Productivity: What Controls the Formation of Organic-Carbon-Rich Sediments and Sedimentary Rocks? AAPG Bull. 1990, 74, 454-466.

38. Philip, H.H. Origin of Phosphatic Black Shale Facies in Pennsylvanian Cyclothems of Mid-Continent North America. AAPG Bull. 1977, 61, 1045-1068.

39. Algeo, T.J.; Kuwahara, K.; Sano, H.; Bates, S.; Lyons, T.; Elswick, E.; Hinnov, L.; Ellwood, B.; Moser, J.; Maynard, J.B. Spatial variation in sediment fluxes, redox conditions, and productivity in the Permian-Triassic Panthalassic Ocean. Palaeogeogr. Palaeoclimatol. Palaeoecol. 2011, 308, 65-83. [CrossRef]

40. Dymond, J.; Collier, R. Particulate barium fluxes and their relationships to biological productivity. Deep Sea Res. Part II Top. Stud. Oceanogr. 1996, 43, 1283-1308. [CrossRef]

41. Dymond, J.; Suess, E.; Lyle, M. Barium in Deep-Sea Sediment: A Geochemical Proxy for Paleoproductivity. Paleoceanography 1992, 7, 163-181. [CrossRef]

42. Filippelli, G.M.; Delaney, M.L. The oceanic phosphorus cycle and continental weathering during the Neogene. Paleoceanography 1994, 9, 643-652. [CrossRef]

43. Luo, Q.; Zhong, N.; Zhu, L.; Wang, Y.; Qin, J.; Qi, L.; Zhang, Y.; Ma, Y. Correlation of burial organic carbon and paleoproductivity in the Mesoproterozoic Hongshuizhuang Formation, northern North China. Chin. Sci. Bull. 2012, 58, 1299-1309. [CrossRef]

44. Murray, R.W.; Leinen, M. Scavenged excess aluminum and its relationship to bulk titanium in biogenic sediment from the central equatorial Pacific Ocean. Geochim. Cosmochim. Acta 1996, 60, 3869-3878. [CrossRef]

45. Paytan, A.; Griffith, E.M. Marine barite: Recorder of variations in ocean export productivity. Deep Sea Res. Part II Top. Stud. Oceanogr. 2007, 54, 687-705. [CrossRef]

46. Algeo, T.J.; Maynard, J.B. Trace-element behavior and redox facies in core shales of Upper Pennsylvanian Kansas-type cyclothems. Chem. Geol. 2004, 206, 289-318. [CrossRef]

47. Grosjean, E.; Adam, P.; Connan, J.; Albrecht, P. Effects of weathering on nickel and vanadyl porphyrins of a Lower Toarcian shale of the Paris basin. Geochim. Cosmochim. Acta 2004, 68, 789-804. [CrossRef]

48. Nameroff, T.J.; Calvert, S.; Murray, J. Glacial-interglacial variability in the eastern tropical North Pacific oxygen minimum zone recorded by redox-sensitive trace metals. Paleoceanography 2004, 19, 373-394. [CrossRef]

49. Piper, D.Z. Seawater as the source of minor elements in black shales, phosphorites and other sedimentary rocks. Chem. Geol. 1994, 114, 95-114. [CrossRef] 
50. Riquier, L.; Tribovillard, N.; Averbuch, O.; Devleeschouwer, X.; Riboulleau, A. The Late Frasnian Kellwasser horizons of the Harz Mountains (Germany): Two oxygen-deficient periods resulting from different mechanisms. Chem. Geol. 2006, 233, 137-155. [CrossRef]

51. Tribovillard, N.; Algeo, T.J.; Lyons, T.; Riboulleau, A. Trace metals as paleoredox and paleoproductivity proxies: An update. Chem. Geol. 2006, 232, 12-32. [CrossRef]

52. Tyrell, T. The relative influences of nitrogen and phosphorus on oceanic primary production. Nature 1999, 400, 525-531. [CrossRef]

53. Francois, R. A study on the regulation of the concentrations of some trace metals ( $\mathrm{Rb}, \mathrm{Sr}, \mathrm{Zn}, \mathrm{Pb}, \mathrm{Cu}, \mathrm{V}, \mathrm{Cr}, \mathrm{Ni}$, Mn and Mo) in Saanich Inlet Sediments, British Columbia, Canada. Mar. Geol. 1988, 83, 285-308. [CrossRef]

54. Piper, D.Z.; Perkins, R.B. A modern vs. Permian black shale-The hydrography, primary productivity, and water-column chemistry of deposition. Chem. Geol. 2004, 206, 177-197. [CrossRef]

55. Rimmer, S.M.; Thompson, J.A.; Goodnight, S.A.; Robl, T.L. Multiple controls on the preservation of organic matter in Devonian-Mississippian marine black shales: Geochemical and petrographic evidence. Palaeogeogr. Palaeoclimatol. Palaeoecol. 2004, 215, 125-154. [CrossRef]

56. Russell, A.D.; Morford, J.L. The behavior of redox-sensitive metals across a laminated-massive-laminated transition in Saanich Inlet, British Columbia. Mar. Geol. 2001, 174, 341-354. [CrossRef]

57. Hatch, J.R.; Leventhal, J.S. Relationship between inferred redox potential of the depositional environment and geochemistry of the Upper Pennsylvanian (Missourian) Stark Shale Member of the Dennis Limestone, Wabaunsee County, Kansas, U.S.A. Chem. Geol. 1992, 99, 65-82. [CrossRef]

58. Jones, B.; Manning, D.A.C. Comparison of geochemical indices used for the interpretation of palaeoredox conditions in ancient mudstones. Chem. Geol. 1994, 111, 111-129. [CrossRef]

59. Yan, D.; Chen, D.; Wang, Q.; Wang, J. Geochemical changes across the Ordovician-Silurian transition on the Yangtze Platform, South China. Sci. China Ser. D 2009, 52, 38-54. [CrossRef]

60. Li, Y.; Lv, H.; Zhang, Y.; Zhang, X.; Shao, D.; Yan, J.; Zhang, T. U-Mo covariation in marine shales of Wufeng-Longmaxi Formations in Sichuan Basin, China and its implication for identification of watermass restriction. Geochimica 2015, 44, 109-116. (In Chinese)

61. Holdaway, H.K.; Clayton, C. Preservation of shell microstructure in silicified brachiopods from the Upper Cretaceous Wilmington Sands of Devon. Geol. Mag. 1982, 119, 371-382. [CrossRef]

62. Wedepohl, K.H. Environmental influences on the chemical composition of shales and clays. Phys. Chem. Earth 1971, 8, 307-333. [CrossRef]

63. Adachi, M.; Yamamoto, K.; Sugisaki, R. Hydrothermal chert and associated siliceous rocks from the northern Pacific their geological significance as indication OD ocean ridge activity. Sediment. Geol. 1986, 47, 125-148. [CrossRef]

64. Yamamoto, K. Geochemical characteristics and depositional environments of cherts and associated rocks in the Franciscan and Shimanto Terranes. Sediment. Geol. 1987, 52, 65-108. [CrossRef]

65. Li, Y.; Shao, D.; Lv, H.; Zhang, Y.; Zhang, X.; Zhang, T. A relationship between elemental geochemical characteristics and organic matter enrichment in marine shale of Wufeng Formation-Longmaxi Formation, Sichuan Basin. Acta Pet. Sin. 2015, 36, 1470-1483. (In Chinese)

66. Li, Y.; Jiang, Z.; Liu, W.; Huang, R.; Zhang, K.; Cheng, S.; Gao, Z.; Gao, F.; Xiong, F. The Effect of the Tectonic Thermal Evolution History to Gas Content of Lower Cambrian Shales at Xiuwu Basin. Sci. Technol. Eng. 2016, 16, 44-51. (In Chinese) [CrossRef]

67. Liu, W.; Tian, J.; Lin, X.; Shi, J.; Yang, C.; Peng, S. Characteristics and significance of mineral compositions in lower Cambrian black shale from Xiuwu Basin, Jiangxi, China. J. Chengdu Univ. Technol. Sci. Technol. 2015, 42, 90-97. (In Chinese)

68. Zhang, Y.; He, Z.; Gao, B.; Liu, Z. Sedimentary environment of the Lower Cambrian organic-rich shale and its influence on organic content in the Upper Yangtze. Pet. Geol. Exp. 2017, 39, 154-161. (In Chinese)

69. Rao, J.; Xiao, H.; Liu, Y.; Bo, D.; Deng, Y. Location of the Yangtze-Cathaysia plate convergence zone in Hunan. Chin. J. Geophys. 2012, 55, 484-502. (In Chinese)

70. Zhang, G.; Guo, A.; Wang, Y.; Li, S.; Dong, Y.; Liu, S.; He, D.; Cheng, S.; Lu, R.; Yao, A. Tectonics of South China continent and its implications. Sci. China Earth Sci. 2013, 43, 1804-1828. (In Chinese) [CrossRef]

71. Mei, L.; Deng, D.; Shen, C.; Liu, Z. Tectonic Dynamics and Marine Hydrocarbon Accumulation of Jiangnan-Xuefeng Uplift. Geol. Sci. Technol. Inf. 2012, 31, 85-93. (In Chinese) 
72. Johnson, J.G.; Klapper, G.; Sandberg, C. Devonian eustatic fluctuations in Euramerica. Geol. Soc. Am. Bull. 1985, 96, 567-587. [CrossRef]

73. Wang, S.F.; Dong, D.Z.; Wang, Y.M.; Li, X.; Huang, J.L. Geochemical characteristics the sedimentation environment of the gas-enriched shale in the Silurian Longmaxi formation in the Sichuan basin. Pet. Geochem. 2015, 34, 1203-1212.

74. Kimura, H.; Watanabe, Y. Ocean anoxia at the Precambrian-Cambrian boundary. Geology 2001, $29,995-998$. [CrossRef]

75. Langmuir, D. Aqueous Environmental Chemistry; Prentice Hall: Upper Saddle River, NJ, USA, 1997.

76. Michard, A.; Albarède, F. The REE content of some hydrothermal fluids. Chem. Geol. 1986, 55, 51-60. [CrossRef]

77. Xu, J.; Liu, Z.; Bechtel, A.; Meng, Q.; Sun, P.; Jia, J.; Cheng, L.; Song, Y. Basin evolution and oil shale deposition during Upper Cretaceous in the Songliao Basin (NE China): Implications from sequence stratigraphy and geochemistry. Int. J. Coal Geol. 2015, 149, 9-23. [CrossRef]

78. Cao, Y.; Wang, Y.; Xu, T. Application of the ratio of characteristic elements in provenance analysis: A case study from the upper part of the fourth member of the Shahejie Fm. in the W58 area, Dongying depression. Acta Sedimentol. Sin. 2007, 25, 230-238. (In Chinese)

79. Ren, J.; Zhang, J.; Liu, S. A review on aluminum to titanium ratio as a geochemical proxy to reconstruct paleopoductivity. Adv. Earth Sci. 2005, 20, 1314-1320. (In Chinese)

80. International Commission on Stratigraphy Homepage. Available online: http://www.stratigraphy.org/ index.php/ics-gssps (accessed on 14 May 2018).

81. Slatt, R.M.; Rodriguez, N.D. Comparative sequence stratigraphy and organic geochemistry of gas shales: Commonality or coincidence? J. Nat. Gas Sci. Eng. 2012, 8, 68-84. [CrossRef]

82. Knauth, L.P.; Epstein, S. Hydrogen and oxygen isotope ratios in nodular and bedded cherts. Geochim. Cosmochim. Acta 1976, 40, 1095-1108. [CrossRef]

83. Hearing, T.W.; Harvey, T.H.P.; Williams, M.; Leng, M.J.; Lamb, A.L.; Wilby, P.R.; Gabbott, S.E.; Pohl, A.; Donnadieu, Y. An early Cambrian greenhouse climate. Sci. Adv. 2018, 4, eaar5690. [CrossRef] [PubMed]

84. Boström, K.; Kraemer, T.; Gartner, S. Provenance and accumulation rates of opaline silica, Al, Ti, Fe, Mn, Cu, $\mathrm{Ni}$ and Co in Pacific pelagic sediments. Chem. Geol. 1973, 11, 123-148. [CrossRef]

85. Liu, J.; Zheng, M.H. Geochemistry of hydrothermal sedimentary silicalite. Acta Geol. Sichuan 1993, 13, 110-118. (In Chinese)

86. Murray, R.W.; Buchholtz Ten Brink, M.R.; Gerlach, D.C.; Russ, G.P.; Jones, D.L. Rare earth, major, and trace elements in chert from the Franciscan Complex and Monterey Group, California: Assessing REE sources to fine-grained marine sediments. Geochim. Cosmochim. Acta 1991, 55, 1875-1895. [CrossRef]

87. Yang, J.M.; Wang, D.H.; Mao, J.; Zhang, Z.H.; Zhang, Z.; Wang, Z.L. The petrochemical research method for silicalite and its application to the "Jingtieshan Type" iron deposits. Acta Pet. Mineral. 1999, 18, 108-118. (In Chinese)

88. Wang, S.; Zou, C.; Dong, D.; Wang, Y.; Huang, J.; Guo, Z. Biogenic silica of organic-rich shale in Sichuan Basin and its significance for shale gas. Acta Sci. Nat. Univ. Pekin. 2014, 50, 476-486.

89. Sun, X.L. Geochemical Characteristics of Organic Matter-rich Sedimentary Strata in Lower Cambrian, Tarim Basin and Its Origins. Acta Sedimentol. Sin. 2004, 22, 547-552.

90. Sun, X.; Chen, J.; Liu, W.; Zhang, S. Hydrothermal Venting on the Seafloor and Formation of Organic-rich Sediments-Evidence from the Neoproterozoic Xiamaling Formation, North China. Geol. Rev. 2003, 49, 588-595.

91. Zhang, W.; Yang, H.; Xie, L.; Yang, Y. Lake-bottom hydrothermal activities and their influence on high-quality source rock development: A case from Chang 7 source rocks in Ordos Basin, China. Pet. Explor. Dev. 2010, 37, 424-429. (In Chinese)

92. Halbach, M.; Koschinsky, A.; Halbach, P. Report on the discovery of Gallionella ferruginea from an active hydrothermal field in the deep sea. Ridge-Crest Res. 2001, 10, 18-20.

93. Korzhinsky, M.A.; Tkachenko, S.I.; Kirill, S.; Taran, Y.; Steinberg, G.S. Discovery of a pure rhenium mineral at Kudriavy Volcano. Nature 1994, 369, 51-52. [CrossRef]

94. McKibben, M.A.; Williams, A.E.; Hall, G.E.M. Solubility and transport of plantinum-group elements and $\mathrm{Au}$ in saline hydrothermal fluids; constraints from geothermal brine data. Econ. Geol. 1990, 85, 1926-1934. [CrossRef] 
95. Taylor, S.R. The Continental Crust: Its Composition and Evolution: An Examination of the Geochemical Record Preserved in Sedimentary Rocks; McClennan, S.M., Ed.; Blackwell Scientific: Oxford, UK, 1985.

96. Li, Z.X.; Zhang, L.; Powell, C.M. South China in Rodinia: Part of the missing link between Australia-East Antarctic and Laurentia? Geology 1995, 23, 407-410. [CrossRef]

97. Wang, J.; Li, Z.-X. History of Neoproterozoic rift basins in South China: Implications for Rodinia break-up. Precambrian Res. 2003, 122, 141-158. [CrossRef] 